\title{
OPTIMALISASI PERAN LINGKUNGAN PENDIDIKAN SECARA TERPADU DALAM MEMBENTUK KARAKTER GO GREEN PESERTA DIDIK
}

\author{
Suharli \\ Dosen FKIP-Universitas Samawa Sumbawa Besar-NTB \\ suharli@fkip.universitassamawa.ac.id
}

\begin{abstract}
Abstrak
Berbagai persoalan dan kerusakan lingkungan menjadi isu utama di Indonesia sebagai akibat dari kegiatan eksploitasi sumber daya alam yang dilakukan oleh manusia secara tidak professional dan ramah lingkungan. Terjadinya eksploitasi sumber daya alam yang tidak ramah lingkungan merupakan wujud merosotnya kesadara dan kepedulian masyarakat sehingga berdampak pada pengrusakan lingkungan. Untuk menumbuhkan kesadaran dan tanggung jawab masyarakat terhadap lingkungan, maka sekolah sebagai lembaga pendidikan merupakan tumpuan utama. Program-program pengembangan sekolah diharapkan agar lebih berwawasan lingkungan sehingga dapat membentuk karakter go green anak didik. Karakter go green merupakan watak dan perilaku cinta lingkungan yang dapat dilakukan melalui kegiatan pembelajaran yang terintegrasi dengan alam secara nyata. Mengingat kegiatan pendidikan buka saja terjadi pada lingkungan sekolah, maka lingkungan keluarga dan masyarakat sebagai lingkungan pendidikan lainnya harus juga dapat dioptimalkan perannya. Oleh karena itu, maka program-program sekolah harus dapat dilakukan secara terpadu dengan melibatkan lingkungan pendidikan keluarga dan masyarakat secara lebih baik melalui kegiatan-kegaiatan nyata di lingkungan alam. Dengan demikian maka karakter go green anak dapat dibentuk secara bersama-sama melalui keterpaduan program anatara program di lingkungan pendidikan formal, lingkungan pendidikan informal dan dan lingkungan nonformal.
\end{abstract}

Kata Kunci: optimalisasi peran, lingkungan terpadu, karakter go green, peserta didik

\section{Pendahuluan}

Berbagai persoalan lingkungan menjadi isu sentral saat ini baik di Indonesia maupun di dunia secara global. Khususnya di Indonesia, kebakaran hutan, banjir, tanah longsor, abrasi, penebangan hutan secara liar, masalah sampah dan masalah lainnya merupakan fokus persoalan yang harus segera menjadi perhatian pemerintah dan seluru masyarakat Indonesia. Semua persoalan tersebut merupakan implikasi dari kegiatan eksploitasi manusia terhadap lingkungan baik secara sengaja maupun tidak sengaja sehingga berpengaruh terhadap kerusakan lingkungan itu sendiri. Misalnya, beberapa kasus kerusakan lingkungan yang dilakukan oleh manusia, seperti banjir dan sampah di Jakarta. Sebagaimana data yang dipaparkan oleh Rifki Afandi (2013: 2) menyebutkan bahwa: 
"Sampah yang dihasilkan kota Jakarta setiap hari mencapai 6000-6500 ton perhari, kerusakan hutan karena penebangan liar menurut Badan Nasional Penanggulangan Bencana mencatat 2,8 juta hektar pertahun di Indonesia hilang sejak tahun 2000-2005, tanah longsor tercatat 530 peristiwa dan menyebabkan 1099 orang meninggal sejak 2002-229, bencana lumpur lapindo di sidoarjo dan sebagainya”.

Bertolak dari data tersebut menunjukkan bahwa begitu rendahnya kesadaran masyarakat terhadap pentingnya perilaku ramah lingkungan. Rendahnya kesadaran tersebut tidak lain adalah wujud dari kemerosotan tata nilai, moral dan tanggung jawab yang terjadi dalam masyarakat. Rendahnya kesadaran masyarakat akan pentingnya berperilaku ramah lingkungan merupakan objek persoalan yang harus mendapatkan penyelesaian, salah satunya melalui proses pendidikan di semua lingkungan. Pendidikan merupakan salah suatu komponen penting dalam menumbuhkan kesadaran dan proses pendewasaan peserta didik sebagai warga Negara. Lagi-lagi sekolah sebagai lingkungan formal pendidikan mengambil bagian dalam menyelesaikan permasalahan global masyarakat melalui proses pembelajaran yang diarahkan pada tumbuhnya kesadaran peserta didik sebagai wujud tanggung jawab dalam melestarikan lingkungan.

Dengan demikian, lembaga pendidikan dan juga guru dewasa ini dihadapkan pada tuntutan yang semakin berat, terutama untuk mempersiapkan peserta didik agar memiliki kepekaan terhadap berbagai persoalan yang terjadi, baik di tingkat lokal maupun di tingkat global serta mampu menghadapi berbagai dinamika perubahan yang berkembang pesat, baik yang berkaitan dengan perkembangan ilmu pengetahuan dan teknologi, juga perubahan dan pergeseran aspek nilai dan moral yang terjadi dalam kehidupan bermasyarakat.

Berbagai fenomena yang terjadi dewasa ini mengisyaratkan hilangnya esensi nilainilai luhur masyarakat yang bersumber dari sosio budaya bangsa seperti nilai-nilai tanggung jawab, kepekaan dan kepedulian terhadap lingkungan, kejujuran, solidaritas, keadilan, persatuan, dan nilai-nilai lainnya. Krisis multidimensi dan keterpurukan bangsa terutama persoalan kerusakan lingkungan pada hakekatnya bersumber dari kegagalan dalam mengaktualisasikan jati diri dan nilai-nilai sosio budaya bangsa serta kegagalan dalam mengembangkan pendidikan yang mengarah pada penanaman nilai-nilai karakter go green peserta didik.

Dalam konteks pendidikan formal di sekolah, salah satu penyebab terjadinya keterpurukan dalam mengaktualisasi nilai-nilai luhur budaya bangsa, karena pendidikan di Indonesia belum berorientasi pada penanaman nilai sikap dan karakter sebagaimana yang 
International Seminar Procedeengs: The Social Studies Contribution to Reach Environmental Education into Stunning Generation 2045. Program Studi Pendidikan Ilmu Pengetahuan Sosial Sekolah Pascasarjana Universitas Pendidikan Indonesia Bandung.

dibutuhkan bangsa. Disamping itu, terjadi pergeseran persepsi orang tua dan masyarakat terhadap proses pendidikan anak. Orang tua dan masyarakat seolah-olah menyerahkan sepenuhnya tanggung jawab pendidikan anakanya kepada pihak sekolah sehingga peran pendidikan informal menjadi sangat minim. Padahal proses pembiasaan dan penanaman nilainilai karakter bangsa termasuk karakter ramah lingkungan merupakan tanggung jawab bersama antara sekolah, keluarga dan masyarakat yang harus dilakukan secara terpadu atau lebih dikenal dengan tripusat pendidikan. Oleh karena itu, upaya untuk mewujudkan peradaban bangsa melalui pendidikan karakter ramah lingkungan sehingga terwujud generasi muda yang berbudaya, bermoral dan cinta lingkungan, maka tidak lain adalah melalui optimalisasi peran lingkungan pendidikan secara terpadu.

\section{Metode}

Penelitian ini menggunakan pendekatan deskriptif kualitatif dengan jenis penelitian kepustakaan. Penelitian kepustakaan merupakan proses melakukan refleksi terhadap berbagai sumber yang dibutuhkan untuk diorganisasikan dan membuat kesimpulan. Menurut Nana Syaodih Sukmadinata (2007 hlm 60-61) yaitu mengumpulkan data yang tertumpu pada penelaahan kritis dan mendalam terhadap bahan-bahan pustaka yang relevan.

\section{Hasil dan Pembahasan}

\section{Esensi Pembentukan Karakter Go Green}

Proses pendidikan anak berlangsung pada berbagai lingkungan mulai dari lingkungan sekolah, keluarga dan masyarakat. Dengan demikian keberhasilan pendidikan anak sangat ditentukan oleh keberhasilan lingkungan tersebut dalam membentuk perilaku yang dibutuhkan oleh anak dalam kehidupannya. Sejalan dengan pentingnya lingkungan pendidikan, secara normatif tujuan pendidikan telah diamanatkan dalam Undang-Undang No. 20 Tahun 2003 disebutkan bahwa pendidikan bertujuan untuk mengembangkan potensi anak agar menjadi manusia yang beriman dan bertqwa kepada Tuhan Yang Maha Esa, berakhlak mulia, sehat, berilmu, cakap, kreatif, mandiri dan menjadi warga negara yang demokratis serta bertanggungjawab. Melalui proses pendidikan siswa diharapkan memperoleh kompetensi secara utuh yang dibutuhkan baik oleh dirinya maupun oleh masyarakt, bangsa dan negara. Dengan demikian, esensi pendidikan adalah membangun individu agar menjadi manusia terdidik atau berpendidikan yaitu manusia yang mampu memahami fenomena secara akurat, berfikir jernih, dan bertindak secara efektif sesuai dengan tujuan dan aspirasi yang ditetapkan oleh dirinya.

Lingkungan pendidikan merupakan wadah perwujudan terbentukan karakter siswa sebagai generasi emas sebagaimana yang diharapkan. Sebagai upaya mewujudkan terbentuknya karakteristik siswa tersebut, maka pendidikan karakter merupakan satu-satunya 
International Seminar Procedeengs: The Social Studies Contribution to Reach Environmental Education into Stunning Generation 2045. Program Studi Pendidikan Ilmu Pengetahuan Sosial Sekolah Pascasarjana Universitas Pendidikan Indonesia Bandung.

yang dapat dijadikan sebagai titik tumpuh. Istilah "karakter" dalam bahasa Yunani dan Latin, character berasal dari kata charassein yang artinya "mengukir corak yang tetap dan tidak terhapuskan". Gene Klann (2007: 6) menjelaskan bahwa Traditionally character has been defined as "the combination of emotional, intellectual, and moral qualities that distinguishes a person." Selanjutnya Marvin W Berkowitz (William Damon, 2002: 69) menjelaskan bahwa, character as an individual's set of fsychological characteristics that affect that person's ability and inclination to function morality. Simply put, character is comprised of those characteristics that led a person to do the right thing or not to do the right thing. Dengan demikian karakter merupakan perpaduan dari segala tabiat manusia yang bersifat tetap dan menjadi karakteristik atau ciri seseorang dalam bersikap dan bertindak sehingga menjadi pembeda antar orang yang satu dengan yang lainnya.

Kohn (Peter Smagorinsky \& Joel Taxel, 2005: 65) menerangkan bahwa, argues that character education programs that emerge from a didactic perspective are collections of "exhortations and extrinsic inducements designed to make children work harder and do what they're told". Their goals, he says, are not concerned with supporting or facilitating children's moral and social growth, but are designed to control students' behavior.

Sejalan dengan itu, pemerintah melalui program kementerian pendidikan nasional tahun 2010-2014 yang dituangkan dalam Rencana Aksi Nasional Pendidikan Karakter disebutkan bahwa pendidikan karakter merupakan pendidikan nilai, pendidikan budi pekerti, pendidikan moral, pendidikan watak yang bertujuan mengembangkan kemampuan peserta didik untuk memberikan keputusan baik buruk, memelihara apa yang baik, dan mewujudkan kebaikan tersebut dalam kehidupan sehari-hari dengan sepenuh hati (Kementrian Pendidikan Nasional Badan Penelitian dan Pengembangan Pusat kurikulum dan Perbukuan, 2011: 7). Dengan demikian, pendidikan pembentukan karakter merupakan upaya untuk menumbuhkan dan mengembangkan nilai-nilai yang baik atau positif pada diri anak sesuai dengan etika moral yang berlaku. Anak tidak hanya tahu apa yang seharusnya dilakukan tetapi juga memahami mengapa hal tersebut dilakukan, sehingga anak akan berperilaku seperti yang diharapkan di lingkungannya.

Pendidikan lingkungan hidup merupakan pendidikan yang lebih menekankan pada pengetahuan, tindakan serta kesadaran masyarakat tentang pendidikan kehidupan berkelanjutan. Bentuk pembelajaran berkelanjutan hidup tidak hanya berupa materi, akan tetapi diperlukan pembelajaran-pembelajaran yang langsung berhubungan dengan alam secara nyata, sehingga pembelajaran yang diberikan lebih mudah difahami dan sesuai sasaran (Ninik Hidayat, 2013:2). Pendidikan merupakan lingkungan belajar yang paling tepat untuk membangun pengetahuan dan kepedulian siswa terhadap pentingnya melestarikan lingkungan 
International Seminar Procedeengs: The Social Studies Contribution to Reach Environmental Education into Stunning Generation 2045. Program Studi Pendidikan Ilmu Pengetahuan Sosial Sekolah Pascasarjana Universitas Pendidikan Indonesia Bandung.

hidup. Menurut Barlia (Rifki Afandi, 2013:3) menjelaskan bahwa pendidikan lingkungan hidup harus dapat mendidik individu-individu peserta didik yang responsive terhadap laju perkembangan teknologi, memahami masalah-masalah di biosfer, dan berketerampilan siap guna produktif untuk menjaga dan melestarikan alam. Dengan demikian pendidikan lingkungan hidup memberikan kontribusi yang cukup besar terhadap pembentukan etika cinta lingkungan sebagai wujud terbentuknya karakter go green peserta didik.

Selanjutnya untuk mewujudkan karakter anak yang peka terhadap lingkungan alam sekitar, maka pendidikan diarahkan pada pendidikan yang berwawasan lingkungan. Pelibatan siswa melestarikan lingkungan agar kembali hijau merupakan upaya menumbuhkan kepedulian dan rasa tanggung jawab yang dinamakan karakter go green atau gerakan menghijaukan kembali. Tanggung jawab tersebut tidaklah bertumpu pada lingkungan pendidikan sekolah semata, akan tetapi melalui pendidikan di lingkungan keluarga dan masyarakat secara terpadu. Titik Setyowati (2013: 2) menjelaskan bahwa go green merupakan gerakan menghijaukan kembali untuk mengantisipasi kerusakan bumi yang disebabkan oleh polusi dari industry, asap kendaraan, kebocoran lapisan ozon, sehingga terjadilah global warming. Untuk menumbuhkan karakter go green tersebut maka pendidikan harus lebih berorientasi pada pemanfaatan lingkungan sebagai sumber belajar sehingga siswa dapat secara langsung merasakan apa yang sebenarnya telah terjadi di sekitarnya.

Sekolah yang peduli dengan lingkunga hidup menurut Rahmat Mulyana (2013: 6) merupakan modal dasar bagi pembentukan etika pada lintas generasi, dan juga merupakan pintu gerbang bagi siswa dalam membentuk perilaku yang ber-etika terhadap lingkungan. Mengacu pada beberapa pendapat tersebut di atas, maka esensi pembentukan karakter go green melalui pendidikan lingkungan hidup tidak lain adalah upaya membangun insan menjadi insan terdidik dan beretika, memiliki kesadaran, kepedulian, dan tanggung jawab, berperilaku dan bersikap positif terhadap lingkungan sehingga terwujudnya kelestarian dan keharmonisan antara manusia dengan alam.

\section{Peran Lingkungan Pendidikan dalam Membentuk Karakter Go Green Anak.}

Pendidikan karakter menjadi isu utama pendidikan saat ini sebagai upaya pembentukan akhlak anak bangsa. Begitu banyak persoalan kerusakan lingkungan hidup menuntut agar generasi bangsa harus memiliki karakter cinta lingkunga atau ramah lingkungan. Karakter ramah lingkungan diharapkan agar generasi bangsa memiliki kepedulian dan rasa tanggung jawab terhadap keseimbangan alam. Dengan demikian sekolah sebagai lingkungan belajar juga dituntut agar peserta didik memiliki karakter tersebut. Akan tetapi pembentukan karakter go green harus dapat dilaksanakan secara terintegrasi dalam 
International Seminar Procedeengs: The Social Studies Contribution to Reach Environmental Education into Stunning Generation 2045. Program Studi Pendidikan Ilmu Pengetahuan Sosial Sekolah Pascasarjana Universitas Pendidikan Indonesia Bandung.

semua lingkungan pendidikan. Selama ini guru dan lembaga sekolah merupakan ujung tombak pelaksana pembelajaran yang diharapkan mampu menerjemahkan dan mengaplikasikan konsep pendidikan karakter go green di kelas. Oleh karena itu, guru dan warga sekolah seakan-akan diserahkan tanggung jawab penuh untuk menumbuhkan dan mengembangkan pendidikan karakter tersebut. Padahal dalam UU No 20 Tahun 2003

Tentang Sistem Pendidikan Nasional pada Pasal 13 Ayat 1 menyebutkan bahwa Jalur pendidikan terdiri atas pendidikan formal, nonformal, dan informal. Pendidikan informal adalah jalur pendidikan keluarga dan lingkungan. Pendidikan informal sesungguhnya memiliki peran dan kontribusi yang sangat besar dalam keberhasilan pendidikan.

Besarnya kontribusi pendidikan informal dalam membentuk karakter anak tidak lain adalah karena keberadaan anak dalam keluarga dan lingkungan sekitarnya kurang lebih sekitar 70\%. Oleh karena itu, jika dilihat dari aspek kuantitas waktu, maka pendidikan di sekolah berkontribusi hanya sebesar $30 \%$ terhadap hasil pendidikan anak.

Selama ini, pendidikan informal terutama dalam lingkungan keluarga perannya dirasakan sangat minim sekali sehingga dapat dikatakan belum memberikan kontribusi berarti dalam mendukung pencapaian kompetensi dan pembentukan karakter anak. Tingginya kesibukan dan aktivitas kerja orang tua, kurangnya perhatian dan pemahaman orang tua dalam mendidik anak di lingkungan keluarga, besarnya pengaruh pergaulan di lingkungan sekitar, serta pengaruh media massa dan elektronik bisa berdampak negatif terhadap perkembangan dan pencapaian hasil belajar anak. Salah satu alternatif untuk mengatasi permasalahan tersebut adalah melalui pendidikan karakter terpadu, yaitu memadukan dan mengoptimalkan kegiatan pendidikan informal lingkungan keluarga dengan pendidikan formal di sekolah. Dalam hal ini, perhatian dan pemahaman orang tua terhadap pentingnya pendidikan anak dalam keluarga dan waktu belajar anak serta pembiasaan-pembiasaan akan nilai-nilai di sekolah perlu dioptimalkan agar peningkatan mutu hasil belajar dapat dicapai, terutama dalam pembentukan karakter anak .

Keluarga merupakan wadah utama dan pertama yang berperan sebagai penyelenggara pendidikan bagi anak-anak baik dalam proses pembudayaan, pemenuhan pengetahuan maupun keterampilan. Keluarga merupakan bagian dari jalur pendidikan luar sekolah yang berperan memberikan keyakinan akan nilai agama, nilai budaya, nilai moral dan keterampilan menuju pada proses pembentukan pribadi yang utuh. Dengan demikian maka, apabila keluarga gagal untuk mengajarkan nilai-nilai tersebut, maka akan sulit sekali bagi institusiinstitusi lain untuk memperbaiki kegagalan-kegagalannya.

Setyowati (2013:3) mnjelaskan bahwa pengenalan nilai-nilai go green yang dilakukan orang tua kepada anak-anaknya dalam rangka pembentukan watak atau karakter, merupakan 
pendidikan akhlak dan moraldalam awal kehidupannya. Kemauan yang teguh untuk ikut melestarikan lingkungan merupakan karakter yang ditanamkan sejak dini sehingga lama kelamaan terinternalisasi pada perilaku anak. Peran orang tua dalam kelurga sangatlah penting sebagai penuntun, pendidik, dan sebagai pemberi contoh. Dengan demikian dari tuntunan yang diberikan oleh orang tua dalam keluarga, maka secara otomatis anak-anak mempraktekkan dan belajar langsung dari apa yang dialami terkait dengan berbagai kegiatan yang sangat berfaedah bagi pendidikan watak dan budi pekerti serta pengembangan perasaan sosial seperti kejujuran, keberanian, ketenangan, hidup hemat, menghargai kebenaran, tenggang rasa, tolong menolong, hidup damai dan lain sebagainya. Oleh karena itu, setiap keluarga harus menyadari bahwa karakter bangsa sangat tergantung pada pendidikan karakter anak di rumah.

Selanjutnya sekolah merupakan jalur pendidikan formal yang menjadi salah satu lingkungan tempat siswa melakukan proses belajar. Di sekolah, guru merupakan teladan bagi siswa dan mempunyai peran yang sangat besar dalam pembentukan karakter siswa. Guru sebagai pendidik mempunyai tanggung jawab yang sangat besar dalam menghasilkan generasi yang berkarakter, berbudaya, bermoral dan cinta lingkungan. Undang-Undang No. 14 tahun 2005 tentang Guru dan Dosen menyatakan bahwa guru sebagai pendidik professional mempunyai tugas utama mendidik, mengajar, membimbing, mengarahkan, melatih, menilai, dan mengevaluasi peserta didik pada pendidikan anak usia dini, pada jalur pendidikan formal, pendidikan dasar, dan pendidikan menengah.

Dengan demikian semakin jelas bahwa peran guru dalam dunia pendidikan sekarang ini semakin meningkat, kompleks, dan berat. Sisi lain memberikan wacana bahwa guru bukan hanya pendidik akademis, tetapi juga pendidik karakter, pendidik budaya, dan pendidik moral bagi para peserta didiknya. Meylan Saleh (2012:7) menjelaskan peranan guru dalam membangun karakter siswa di sekolah (1) guru sebagai teladan bagi siswa, merupakan faktor mutlak yang harus digugu dan ditiru; (2) guru sebagai inspirator, merupakan pembangkit semangat peserta didik untuk maju dalam mengembangkan potensi dirinya; (3) guru sebagai motivator, merupakan pembangkit spirit, etos kerja dan potensi yang luar biasa pada peserta didik; (4) guru sebagai dinamisator, merupakan pendorong pencapaian tujuan siswa dengan penuh kearifan, kesabaran, cekatan, cerdas, dan menjunjung tinggi spiritualitas; (5) guru sebagai evaluator, merupakan kemampuan dalam melakukan evaluasi terhadap sikap diri, metode yang digunakan dalam membangun karakter anak sehingga dapat diketahui tingkat keefektifannya". 
Mengingat begitu kompleknya peran guru dalam membangun karakter anak, maka secara kelembagaan semua pengembangan sekolah harus mengarah pada pencapaian tujuan tersebut, termasuk di dalamnya adalah pencapaian karakter go green. Sampai saat ini memang sudah banyak lembaga yang berkecimpung dalam pelestarian lingkungan, akan tetapi sekolah tetap menjadi tumpuan utama dalam melahirkan generasi sebagimana yang diharapkan. Melalui proses pembelajaran, anak harus dilibatkan pada program yang terintegrasi dengan lingkungan dan juga harus didukung oleh pembiasaan-pembiasaan yang dapat dilakukan dilingkungan keluarga dan masyarakat. Keterpaduan program sekolah, keluarga dan masyarakat, menurut hemat penulis sangatlah penting untuk dicoba agar keluarga dan masyarakat ikut bertanggung jawab terhadap keterampilan apa yang semestinya dimiliki oleh anak untuk diaplikasikan di lingkungannya. Mengingat begitu sibuknya orang tua di rumah sehingga ketika anaknya pulang sekolah hampir tidak sempat mengontrol apa yang telah dipelajari oleh anaknya di sekolah. Oleh karena itu, karakter go green anak dapat ditumbuhkan secara optimal apabila semua arah pengembangan sekolah diupayakan pada pelestarian lingkungan dengan melibatkan orang tua, siswa dan warga sekolah ke dalam masyarakat melalui kegiatan yang sudah terprogram.

Sejalan dengan upaya membentuk karakter anak yang cinta lingkungan, menurut Ninik Hidayati, dkk. 2013:4-5) menyebutkan bahwa baik pengembangan sekolah, pengembangan kurikulum, pengembangan kegiatan sekolah, pengembangan dan pengelolaan sarana pendukung sekolah semuanya harus berbasis partisifatif dan berwawaswan lingkungan. Mungkin sudah banyak sekolah yang mencoba untuk mengarahkan programnya pada pelestarian lingkungan, akan tetapi menurut hemat penulis mungkin masih sedikit sekolah berupaya melibatkan lingkungan pendidikan secara terpadu dan terprogram (sekolah, keluarga, dan masyarakat) melalui kegiatan yang sudah dirintis di sekolah. Oleh karena itu sekolah harus lebih intensif melakukan interaksi dengan orang tua siswa dan masyarakat sebagai wujud kontrol aktivitas anak, baik yang berhubungan dengan pelajaran di sekolah maupun kegiatan-kegiatan sosial lainnya.

\section{PENUTUP}

Pendidikan merupakan tumpuan utama dalam membentuk anak didik yang syarat dengan ilmu pengetahuan dan nilai-nilai karakter bangsa. Kegiatan pendidikan dapat berlangsung pada jenis, jalur, jenjang dan lingkungan yang beragam. Proses pendidikan anak dewasa ini terlihat lebih dominan pada lingkungan pendidikan formal, sementara lingkungan pendidikan keluarga dan masyarakat sedikit terkikis perannya sehingga jika terjadi masalah 
pada dimensi moral anak, maka yang harus bertanggung jawab adalah guru dan sekolahlah. Oleh karena itu ruh pendidikan di lingkungan keluarga dan masyarakat harus dibangkitkan kembali agar semua lingkungan pendidikan ikut bertanggung jawab terhadap proses pendewasaan anak. Sekolah harus mencoba menyusun program-program tertentu yang dapat melibatkan orang tua, siswa dan masyarakat terutama program-program yang berwawasan lingkungan. Dengan demikian maka interaksi sekolah, keluarga dan masyarakat harus dapat dilakukan secara lebih baik sehingga kontrol terhadap berbagai kegiatan dan aktifitas anak dapat dilakukan secara terpadu.

\section{Daftar Pustaka:}

Damon, William. 2002. Bringing In A New Era In Character Education. Stanford University: CA. hoover institution press.

Gene Klann. 2007. Building Character. Strengthening The Heart Of Good Leadership. San Francisco: Jossey bass.

Meylan Saleh. 2012. Peran Guru dalam Menanamkan Pendidikan Karakter Anak Usia Dini di PAUD Se-Kecamatan Limboto. Jurnal Pedagogika. Ilmu Pendidikan. Volume 3/No 24. Desember 2012.

Ninik Hidayati, dkk. 2013. Perilaku Warga Sekolah dalam Program Adiwiyata di SMK 2 semarang. UNDIP Semarang: Proseding Seminar Nasional Pengelolaan Sumber Daya Alam dan Lingkungan.

Peter Smagorinsky \& Joel Taxel. 2005. The Discourse of Character Education. Culture Wars in the Classroom. London. Laurence Erlbaum Associates Publishers.

Rachmat Mulyana. 2009. Penanaman etika lingkungan melalui sekola peduli dan berbudaya lingkungan. Jurnal tabularasa PPs Unimed. Volume 6 no 2 Desember 2009.

Rifki Afandi. 2013. Integrasi Pendidikan Lingkungan Hidup Melalui Pembelajaran IPS di SD Sebagai Alternative Sekolah Hijau. Universitas Muhammadiyah Sidoarjo: Jurnal vedagogika volume 2 no 1, Februari 2013.

Tsabit Azinar Ahmad. 2013. Pembelajaran Sejarah Berwawasan Lingkungan.Indonesian Jurnal Conservation. Volume 2 No 1-Juni 2013.

Udin Saripudin Winataputra. 2010. Implementasi Kebijakan Nasional Pembangunan Karakter Bangsa Melalui Pendidikan Karakter. Konsep, Kebijakan dan Kerangka Pragmatik. PPs UT. 